超音波流速分布計測法による液体金属流動計測*

（第 1 報, LBE ターゲットの流動計測）

\author{
大林 寛 生 ${ }^{* 1}$, 田 坂 裕 司*2, 森 永 聖 人1 $^{* 1}$ \\ 武田靖*2, 菊 地賢司*3
}

\title{
Measurement of Liquid Metal Flow using Ultrasonic Velocity Profiler (1st Report, Flow Measurement of LBE Target)
}

\author{
Hironari OBAYASHI*4, Yuji TASAKA, Masato MORINAGA, \\ Yasushi TAKEDA and Kenji KIKUCHI \\ ${ }^{* 4}$ Division of Mechanical Science, Graduate School of Engineering, Hokkaido University, \\ N 13 W 8, Kita-ku, Sapporo-shi, Hokkaido, 060-8628 Japan
}

\begin{abstract}
Ultrasonic Velocity profiler (UVP) is a powerful tool to measure an instantaneous velocity profile especially on a velocity measurement of an opaque liquid flow, such as liquid metal. In this study, UVP is applied to a velocity field measurement of a fluid flow of Lead Bismuth Eutectic (LBE) in the Accelerator Drive System (ADS). At a lower temperature, wetting of LBE to stainless steel that is a material of target loop is too poor. We solved this problem by solder coating of the measurement window of the target loop. We performed velocity measurement on the centerline of the loop and confirmed basic performance of the loop. It was found that there was intermittent release of eddy from the re-circulation region formed on a wall surface of an inner cylinder and behind the edge. We made then a measurement for an angluar direction of circumference around the central axis and obserbed 3-dimensional structure of LBE flow of the loop. From these results, we made clear that UVP is highly effective in a measurement of the flow field of liquid metal.
\end{abstract}

Key Words: Liquid Metal, LBE, Ultrasonic Velocity Profiler, Instantaneous Velocity Profile, Wetting

\section{1. 锖}

ナトリウムや水銀などの液体金属は，その他の液 体に比べて熱容量が非常に大きいため, 高エネルギー を発生させる装置の冷媒として広く使用されている. しかしながら，液体金属の挙動は非常に複雑であり， その影響を考慮した装置の設計，およびその制御は非 常に困難である. 液体金属の挙動を把握するためには その流動場を詳しく知る必要があり，またその制御の ためには, 従来のような温度変化の監視だけではなく, 瞬時流動場を常にモニタリングする必要がある. しか しながら，そのような手法は現在のところ実現されて いない，また液体金属は，MHD や地球流体力学の基

\footnotetext{
* 原稿受付 2005 年 6 月 8 日.

*1 北海道大学大学院工学研究科( $060-8628$ 札幌市北区北 13 条西 8).

*2 正員, 北海道大学大学院工学研究科.

*3 正員, 日本原子力研究開発機構東海研究所 (-319-1195 茨 城県那珂郡東海村白方白根 2-4).

E-mail : oobayashi@ring-me.eng.hokudai.ac.jp
}

磷的な研究に使用されている ${ }^{(1)-(4)}$ ，磁場队熱，回転な ど設定パラメータが多いこれらの研究分野では，効率 よくその流動場を計測できる手法の開発が望まれてい る. しかしながら液体金属は不透明であるため, LDA やPIVなどの光学的な手法は使用できない.

液体金属の流動計測法としては，例えば中性子を 用いて液体金属内の気泡や粒子の運動を調べる力法のの などがある. これらの手法は基本的に流れ場の面計測 であり，得られる情報量も膨大である. しかしながら， 取扱の面から上記の目的にはそぐわない，そこで本研 究では，超音波バーストを用いた流速分布計測法

(Ultrasonic Velocity Profiler, UVP) のによる，種々の 液体金属の流動場計測を行う.

UVP は流体の透明性を問わず，瞬時速度分布の計 測が可能であることから，近年，実験流体力学におけ る有効な手法(8)(9)として，また流体工学における計測 法(10)(1I) として応用されている. UVP の特徵は，大規 模な装置や煩雑な操作，また計測結果を得るためのポ 
ストプロセッシングを必要としないことである. よっ て, 補正を必要としない瞬時の速度分布であれば, リ アルタイムでのモニタリングが可能である. これが他 の流動場計測手法と一線を画す点である.さらに，測 定速度範囲や測定速度成分の拡張を目的とした改良 (ロ胡分行われており，不透明液体の流動場計測に関し ては類を見ない非常に強力な手法である.このように, 非常に利便性の高いUVP であるが，目に見えない超 音波の特性上，使用に際しては種々の注意が必要とな る. そこで本研究では，UVP を液体金属流動に適用 する上での問題点を指摘し，その対処法を示す.

現在, 日本原子力研究所で開発が進められている 加速器駆動核変換装置 (Accelerator Drive System, ADS）の核破砕ターダットおよび未臨界炉の椧却材 として，溶融鉛ビスマス (Lead Bismuth Eutectic, 以下 LBE と略記）を使用することが检討されている. し かしながら実用化にあたり，LBEによる装置材料の腐 食予測や伝熱特性の評価など課題は多く，またそれら を解決するためには LBE の流動状態を把握すること が必要である.これまでに, 高レイノルズ数と高ぺク レ数を想定した伝熱特性の数值シミュレーションが行 われてきたが，陽子ビーム入射空の除熱設計に際し， 伝熱特性が用いる計算モデルによって計算結果が異な るなどの問題が生じている. 特に LBE が構造物と衝 突して流れが乱れる箇所では, 局所流れの把握無しに 伝熱特性を評価することは困難である.このため, LBE の流動計測は不可避であるが，これまでにその計 測を行った例は極めて少ない，その理由として，LBE の融点が $125^{\circ} \mathrm{C}$ と高温であること，光学的計測が不可 能な不透明流体であることなどが挙げられる，本報告 では UVPを LBE の速度場計測に適用し，得られた結 果について考察する。

\section{UVP の測定原理}

UVP は，超音波バーストを微小な反射体を含ん
だ流体中に照射し，返されるエコ一信号を解析する ことで, 瞬時の速度分布情報を時系列で獲得する手 法である，得られる速度成分は，流れ場の速度べク トルを測定線（超音波ビームの飛行方向）に投影し た成分であり，これが測定線に沿って計測される. このとき, 時刻 $t$ における瞬時速度分布 $V(x, t)$ と測 定位置 $x$ は以下の式で決定される.

$$
\begin{aligned}
& V(x, t)=\frac{c f_{D}}{2 f_{0}} \\
& x=\frac{c \tau}{2}
\end{aligned}
$$

ここで，cは流体中の音速， $\tau$ は超音波パルスの飛 行時間, $f_{0}$ は超音波パルスビームの基本周波数, $f_{\mathrm{D}}$ はドップラーシフト周波数を表している. UVP に

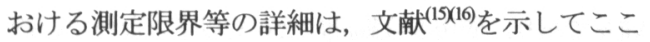
では説明を省略する.

UVP による計測において注意すべき点として, 計測線上に存在する気液または固液界面の状態が举 げられる. 解析対象となる微粒子からの反射波に, そのような界面からの多重反射波など，想定外の強 い反射波が重畳する場合, 微小な反射体からの反射 波に対する SNA゙悪くなり, 得られる速度分布に影 響を与える. 結果として計測の正当性が保証されな くなるため，充分な注意が必要である。

\section{3.ターゲット内部流動場計測の根要}

計測対象となる核変換ターグットモデルループ(か) JAERI Lead Bismuth Loop-2 (JLBL-2)の概略を図 1 に示寸. ループは円筒 2 重管となっており, 内円筒の内径は $355 \mathrm{~mm}$, 外形 $63 \mathrm{~mm}$ である. また, 内円筒と外円筒 の間隙 $3 \mathrm{~mm}$, 全長は $15045 \mathrm{~mm}$ であり, 重力方向に対 して水平に設置されている.ループ中に満たされた流 体は, 円筒 2 重管の外部に取り付けられた電磁ポンプ により駆動され，円筒間の間隙を通過する. その後, 湾曲した形状を持つ端部で合流・反転し，内円筒中に

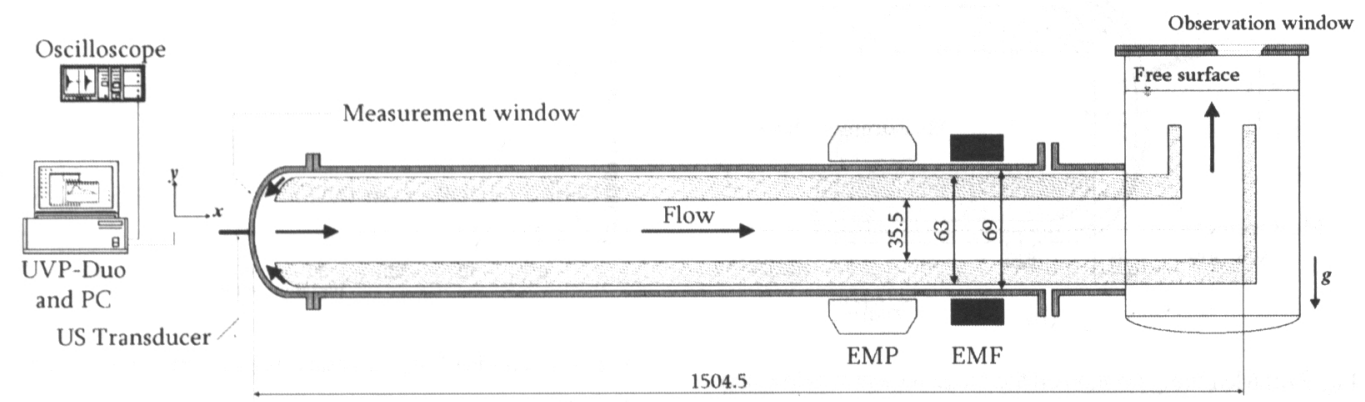

Fig. 1 Experimental setup and schematic illustration of JLBL-2 
逆向きの流れを形成する. 実際のターゲットでは, こ の湾曲部を空として陽子ビームを入射させるため, こ の付近の局所的な流動特性が除熱設計を行う上で非常 に重要となる. 材料の耐腐食性等を考慮して, ターゲ ットは主にステンレス製であり, ループインベントリ 一 (タンク容量) は251となっている. 作動流体であ る LBE の温度は; 超音波トランスデューサの耐熱温 度を考虑し, $150{ }^{\circ} \mathrm{C}$ した. 流量の監視には, 原子力 研究所により開発された新型の電磁流量計(肉を用いた. 計測システムにはUVPMonitormodel-Duo（Met-Flow社 製) (9を使用した. 超音波バースト信号の送受信には， $150{ }^{\circ} \mathrm{C}$ 高温流動場においてあらかじめ耐熱実験の検 証を行った, 超音波トランスデューサ（Met - Flow 社 製）を用いた. トランスデューサの基本周波数は 4 $\mathrm{MHz}$ であり，使用温度範讲は $250^{\circ} \mathrm{C}$ 以下となっている. LBEのタンク自由界面で巻き込まれる空気気泡を, 流 れをトレースする超音波の反射体として用いた. 流動 場計測は, 仮想陽子ビーム空部である, 厚さ $35 \mathrm{~mm}$ の湾曲したループ端部で行った. 図 2 (a)は, 空部の正 面図である. 図のように, 計測位置は空部中央および 空部中央を中心とした半径 $14 \mathrm{~mm}$ の円弧上の，45 間 隔の8点である. なお, 図2(b)に示すように, 超音波

$180^{\circ}$ (E)

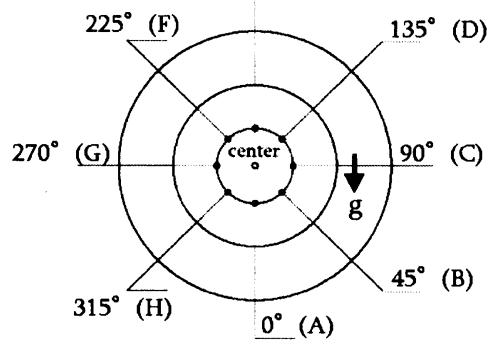

(a)

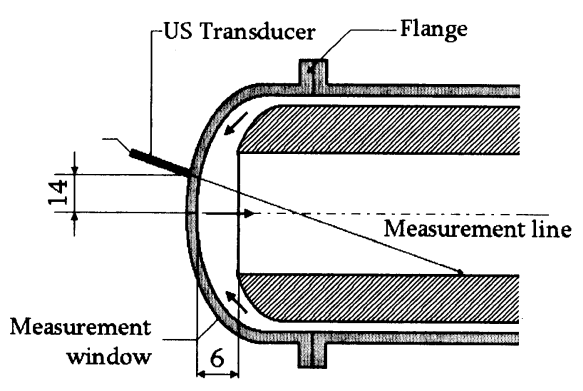

(b)

Fig. 2 (a) Measuring position on the measurement window and (b) side view of the measurement part with measuring line
ビームの届折などを考慮し, トランスデューサは空 部表面に対し，常に垂直となるように設置した。

電磁ポンプで流量を変化させ, 空部中央に固定し たトランスデューサにより，それぞれの流速条件に ついてループ中心軸上の流れ方向速度分布を計測し た. また流量を一定値とし, 中心軸から $14 \mathrm{~mm} の$ 距離に配置した計 8 点の測定点において, 中心軸周 りの角度方向に対しての流動計測を行ない, ビーム 空部近傍における流れ場の 3 次元性を検郡した. 図 2 (b)に示すように, この場合の計測線はループの 端部と中心軸を通過し，内円筒内壁に達する．また， 周方向の各計測位置における計測線は対称関係にあ るため, 流動場の角度方向に対する評価が可能であ る.

\section{4. 流れ性および超音波の伝播}

ADS の運用時において, LBE の温度は $500^{\circ} \mathrm{C} に$ 達 することが想定されている.これに対し本研究では, 前述のように LBE の温度を $150^{\circ} \mathrm{C}$ と比較的低温に設 定している. この場合, 融点付近の温度範囲におい て LBE の表面張力が大きいため, ステンレス管壁 面との濡れ性が不十分であることが予想される.こ のような不十分な濡れ性は, 固体境界面での流れに 対する条件を変えるだけではなく，UVP を使用す る上で以下のような計測上の問題が発生する.

図 3 に, UVP による流動場計測結果の一例を示 す. 分布は, 空部中央から計測した内円筒中心軸上 の瞬時速度分布を平均して得られた, 時間平均速度 分布を示している. 図の横軸は計測開始位置からの 距離, 綐軸は計測線方向の速度であり, トランスデ ューサから遠ざかる成分が正の值として表されてい る. 測定された速度は, $15 \mathrm{~mm}$ 付近で急激に增加 し, その後徐々に減少しているが， 30 および 43

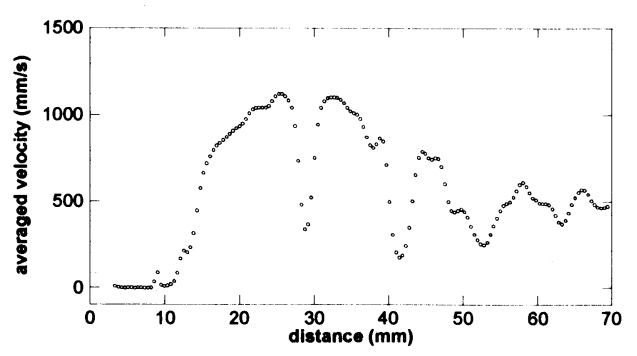

Fig. 3 Example of time averaged velocity profile on the center line of the inner cylinder 


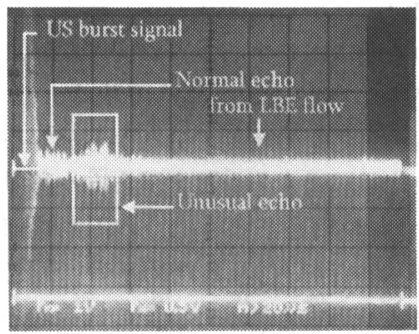

Fig. 4 Photograph of the ultrasonic echo from the LBE flow shown by an oscilloscope

$\mathrm{mm}$ 付近に, 局所的な速度の落ち込みが見られる. これらの点において, 速度はゼロ付近まで減少して いる.このような速度の落ち込みは, 計測線が固体 面に接触する際に生じるが, 図 2 (b)に示されるよう に，計測線上にそのような固体面はなく，これらの 速度の落ち込みは明らかに不自然である。

図 4 は計測中のオシロスコープの画面を撮影した ものであり, 瞬時速度分布の算出に用いた, 流れ場 からの超音波エコ一信号の状態を表している. なお, 画面左端の大きな振幅の波形は, 流れ場に照射した 超音波バースト信号を示している. 図中に示した枠 内の位置に，流れ場からのエコーと比較して大きな 振幅を持つ信号が確認できる. 超音波バーストの発 射からこの信号が検出されるまでの時間を，LBE 中の音速を用いて距離に換算したところ, 計測結果 において速度の落ち込みが見られた測定線上の距離, 約 $30 \mathrm{~mm}$ とほぼ一致した. すなわち, 測定結果に 現れた速度分布の落ち込みは, 超音波エコー信号に このような予期せ信号が含まれていた結果, 算出 されたものである.この異常な信号は, 以下のよう な超音波の伝播により生じたと考える. 装置内壁と LBE との濡れが不十分な場合, トランスデューサ から発射された超音波バーストの一部はループ内の LBE へ透過せず, 曲面である空部内壁面で反射し た後ステンレス製の空部を伝播し, 図 2 (b)に示した フランジ部分で反射される. 実際に, オシロスコー プにより得られた信号の検出時間を, ステンレス中 を伝播する縦波の音速（5790 m/s） を用いて距離に 換算したところ, フランジの位置とほぼ一致する距 離が得られた。

このような, 濡れ性が不十分な場合のみならず, 管壁等を介して作動流体と非接触で計測を行う場合, 管壁材と作動流体との音響インピーダンスの違いか ら，流体中ではなく管壁を伝播する超音波の影響は

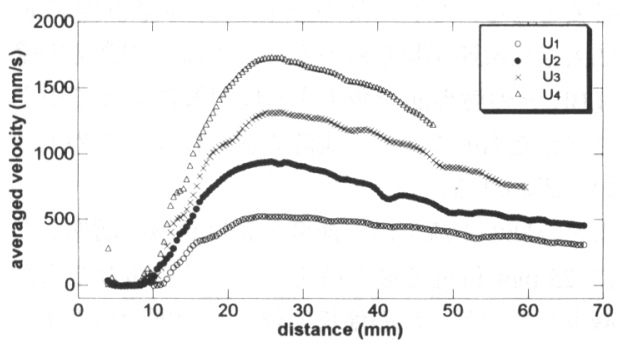

Fig. 5 Averaged velocity profile along the centerline of the inner cylinder, where conditions are: $\mathrm{U}_{1}, \mathrm{U}_{2}, \mathrm{U}_{3}, \mathrm{U}_{4}=0.25,0.50$, $0.75,1.00 \mathrm{~m} / \mathrm{s}$.

避けられない. よってそのような場合には, 得られ る速度分布とともに, オシロスコープなどにより超 音波エコー信号をモニタリングし, その状態を常に 観察することが重要である. なお本実験では濡れ性 問題解決のため, 計測部内壁面に LBE と比較的濡 れ性の良いはんだによるコーティングを施し, 常に その状態が維持されていることを確認するため, 反 射波の状態をオシロスコープで監視しながら計測を 行った. また, ループを数時間駆動させた後, 装置 内壁に形成される鉛被膜の厚さは $20 \mu \mathrm{m}$ 以下になる ため, ループ内部の流れを乱すことはないと考える.

\section{5. 流動場計測結果}

5.1 中心軸上速度分布 図 5 に, 内円筒中心 軸上での速度分布計測の結果を示す. 図中の横軸は 計測位置を表し, 装置内壁端面を原点としたターダ ット中心軸上の距離に対応している.また縦軸は, 計測された速度分布の時間平均結果を表している. 計測は, 上流の環状部に設置された電磁流量計によ り計測される平均流速 $U$ を, $0.25,0.50,0.75,1.00 \mathrm{~m} / \mathrm{s}$ の4段階に変化させて行った.

すべての条件において, 得られた速度分布は装置 内壁端面から $10 \mathrm{~mm}$ 付近までは速度ゼロの值を示 している. 計測開始位置, すなわちループ最端面近 傍では外円筒からの流れが互いに衝突するため, そ の中心部では局所的なよどみ領域が形成されること が予想される. 計測結果はこのようなよどみ域を表 しており, その領域は中心部では壁面から $10 \mathrm{~mm}$ 付近にまで及んでいる. このよどみ域の幅は, 流量 の増加に対して減少する傾向を示しているが, その 減少率は非常に小さく, たとえ装置流量を増加させ てもよどみ域の形成は避けられない. 陽子ビーム入 射時には，このよどみ点が除熱の妨げとなることが 予想されるため, 流量を増加させること以外の対策 
が必要となる．なお一部の分布には，計測開始点近 傍に大きな流速が見られるが，これは計測空部内壁 と LBE との境界面で発生する反射波によって引き 起こされたものであり，実際の流れによるものでは ないと思われる.

よどみ域の下流では, 速度分布は急激に增加した 後に $25 \mathrm{~mm}$ 付近で最大值をとり, その後なだらか に减少している，Uの増加に対し，速度分布の示寸 最大流速は比例関係にあるが, その後の减少は比例 関係に無い. 今回使用したループ形状の性質上, 内 円筒端部では管壁近傍に流れの再循環領域が形成さ れる. この再循環領域の存在する箇所では主流方向 の流れに縮流現象が生じるため，このような計測結 果が得られたと考えられる.

\section{2 流れの時空间变的特性 図6に，ある時刻} における一連の瞬時速度分布を示す。これらは, 計 測開始から $3.675 \mathrm{~s}$ 後の 3 時刻にわたり測定されたも のであり, 各瞬時速度分布の時間間隔は $49 \mathrm{~ms}$ であ る、平均流量条件は $U=0.5 \mathrm{~m} / \mathrm{s}$ であり, 図 5 に示し た平均速度分布の, $\mathrm{U}_{2}$ の場合に相当する.

図 6に示した各時刻の瞬時速度分布形状は，全体 的には図 5 に示した平均速度分布と大きな差はない， しかしながら局所的には, 平均速度分布には現れな い，大きな速度の変化が見られる. 例えば測定時間 $3.675 \mathrm{~s}$ の分布では, 図中に矢印で示すように $28 \mathrm{~mm}$ 付近に局所的な速度の落ち込みが確認できる.この 速度の落ち込みは, この時刻の速度分布のみに現れ ること, また速度がゼロに達するような極端な落ち
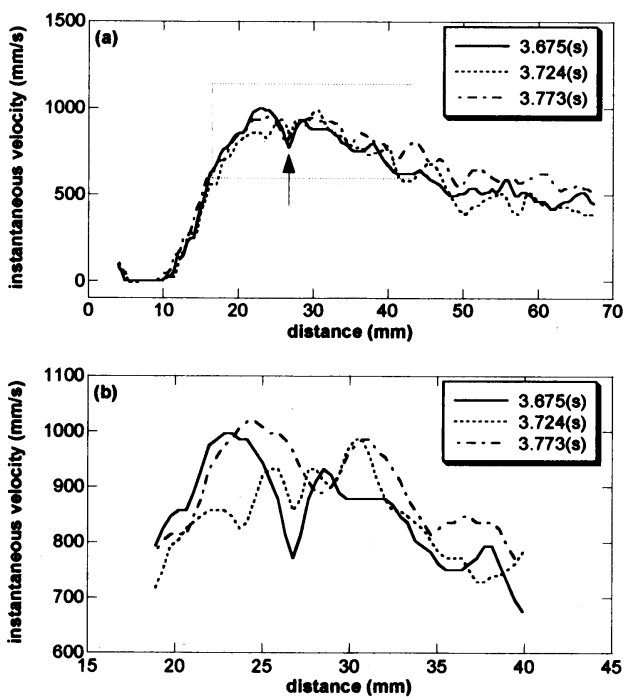

Fig. 6 (a) Series of instantaneous velocity profile, (b) Enlanged figure of enclosed part in (a)
込みではないことから, 図 3で示したような予期せ ぬ反射波の干涉により生じたものではない.この速 度の落ち込みの存在領域は極めて狭く, $1 \sim 3 \mathrm{~mm}$ 程度である. また他の時刻の分布から分かるように, この領域は時間経過とともに主流方向一移動してい る. 3.1 節でも説明したように, 内円筒端部では流 れの方向が $90^{\circ}$ 曲げられるため, 管壁近傍に流れ の再循噮領域が形成される. 上記の結果からこの速 度の落ち込みは, その再循環領域から放出された渦 によるものであると考える. また瞬時速度分布の計 測結果から，このような渦放出は周期的ではなく， 何らかの要因により非周期的に行われていることが 分かる. 陽子ビーム入射時の除熱を考えた場合, 再 循環領域の形成はその妨げとなるため, このような 渦放出はむしろ歓迎すべきものである．流れに対し て積極的に擋乱を与えることにより，このような渦 放出を促進することで，除熱能力をさらに高めるこ とができると考える.

5.3 速度分布の非効対称性封プが横置きで あるため流れに働く重力が軸対称ではないこと，環 状流路に対して一様にLBE を流すことが非常に困 難であることなどから，陽子ビーム空近傍や内円筒 内においても流れが非軸対称性を有することが予想 される. 本実験ではこの非対称性を評価するため, 図 2 に示したように空部中心を取り囲む8 本の計測 線について速度分布計測を行った。計測結果を図 7 に示す. 結果は, 平均流速を示しており，(A)〜 (H) の各分布はそれぞれ, 垂直下部から反時計回りに $45^{\circ}$ ごとの測定結果を示している. なお，計測時の 平均流速条件は $U=0.50 \mathrm{~m} / \mathrm{s}$ である.

得られた速度分布は, 図 5 に示した内円筒中心軸 上の速度分布と同様に，入射空近傍に $10 \mathrm{~mm}$ 程度 の長さの低流速域を有しており，5.1 節で示したよ どみ領域が広籁囲にわたって存在していることが分 かる. この領域を経た後, 速度は徐々に増加し内円 筒中央(66 mm)よりも手前で最大值をとっている. なお，これらの速度分布計測は空部中央よりも曲率 の大きい面を通して行っているため, 先に示した反 射波の影響を受けやすく，図 7に示す速度分布は中 心部のものに比べてやや乱れた分布となっている. しかしながら，そのような乱れは局所的であり，流 速分布の角度方向依存性を分布全体として評価する ことに対して大きな妨げにはならない。

ループ垂直断面の速度分布を示す，図 7 (A)と(E) の測定結果を比較すると, ループ上部側 (E) が下部 側の (A)よりも高い流速を示しており, 最大流速に 

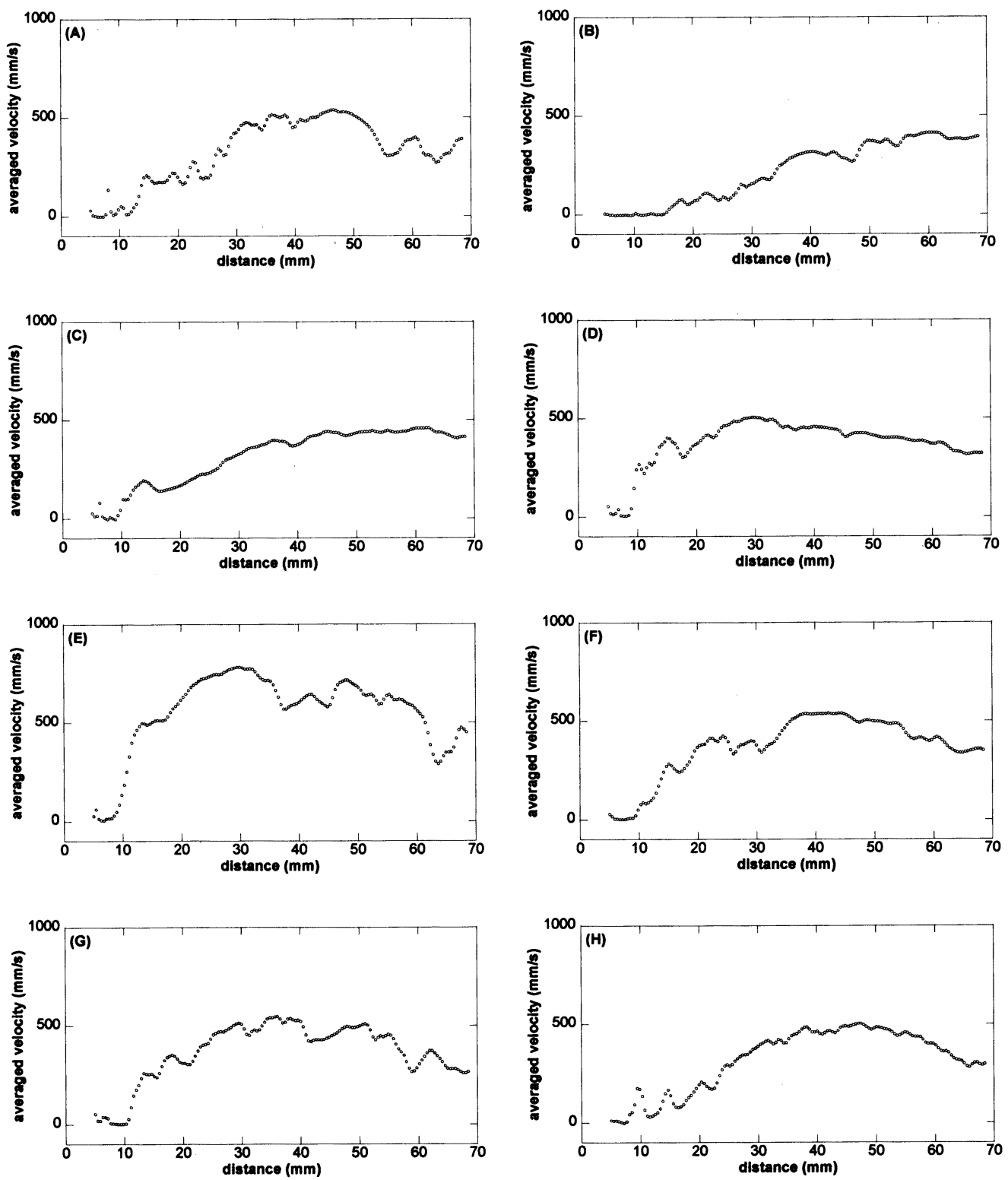

Fig 7 Averaged velocity profiles measured around the centerine of the measurement window at even intervals of angle, where measurement position labeled with (A) to (G) are expressed in Figure 2(a) (velocity condition is $0.50 \mathrm{~m} / \mathrm{s}$ ), Position of the center of imer cylinder on the measurement line is $66 \mathrm{~mm}$.

到達する位置に関しても(E)がより入射空側に偏つ ている. このことから，LBE の流れには重力方向 に偏りが存在し, 5.1 節で示したよどみ領域がルー プ下部方向に偏っていることが考えられる. 更に (B)の分布に注目すると，入射窓近傍のよどみ域を
経た後の, 速度の増加が他の分布に比べて緩やかで あり，測定範囲内では極大值を持たないことが分か る. また(B)に隣接した (C) の分布は, 分布形状が (B)と似ており, (B)の分布とその他の分布の中間形 状であると見なせる.このことから，重力の影響に 
加え，環状部での一様な流が実現されていないこと などにより，低流速のよどみ領域はループ右下部の (B)と (C) 側に偏っており，LBEの流れがループ上部 に偏っていることが予想される.

\section{6. 结}

超音波流速分布計測法（UVP）を用いて，溶融鉛 ビスマス（LBE）の流動計測を行った．速度データに 欠損がある場合の速度分布と超音波エコーの波形を示 し，液体金属流れの計測における問題点を示した。 す なわち，液体金属は融点付近での表面張力が大きく濡 れ性が非常に悪いため，固体壁からの反射波の影響を 受けやすい，そのため，超音波エコーの状態を常に観 察する必要があることを指摘した，得られた速度分布 を解析することにより，以下の結論を得た。

(1) LBEが旋回・合流する陽子ビーム入射空近傍には， 広範用にわたり $10 \mathrm{~mm}$ 程度の幅のよどみ域が形成 されており，この範冊は流量を増加させてもほと んど変化しない.

（2）内円筒管壁の近傍に形成される再循環領域からは, 非定期的に小さな渦が放出されており，除熱効果 を上げるためにはこのような渦放出を活発にさせ る必要がある.

（3）ループ内の流れには強い三次元性が存在し，流れ はループ上部に偏っている.

これらの結果から、ループの流れをある程度予測す ることは可能である. しかしながら計測法の特性上, ループ内の流れ場全体を把握することは容易ではない． よって実際には，数值計算結果との比較によりその妥 当性を確認し，それらの結果を相補的に用いることに よりループ内の流動を評価する必要がある.

\section{7. 碀辞}

本研究の一部は, 電源開発促進対策特別会計法に 基づく文部科学省からの受託事業として, 日本原子 力研究所が実施した平成 16 年度「加速器駆動核変 換システムの技術開発等」の成果です。
また，本研究の実験を遂行するに際し，助川電気 工業（株）手塚正雄氏の協力を得たので，謹んで謝 意を評します。

\section{考文献}

(1) Morley, N. B. and Buris, J., Fusion Sci. Technol, 441, (2003), pp.74-78.

(2) Borgstedt, H. U., et al., J. Nucl. Mater, 212/215, (1994), pp.1501-1503.

(3) Rossby, H. T., J. Fluid Mech, 36, (1969), pp.309-338.

(4) Brito, D., et al., Phys. of Earth \& Planet. Int, 91, (1995), pp.77-98.

(5) Mishima, K. et al, Nucl. Eng. Design, 189, (1999), pp.391403.

(6) Saito, Y., et al., Appl. Radiation \& Isotopes, 61, (2004), pp.667-674.

(7) Takeda, Y., Int. J. Heat Fluid Flow, 7, (1986), pp.313-318.

(8) Takeda, Y., J. Fluid Mech, 389, (1999), pp.81-99.

(9) Schouveiler, L., et al, Exp. Fluids, 26, (1999), pp.179-187.

(10) Mori, M., et al., Exp. Fluids, 32, (2002), pp.153-160.

(11) Ouriev, B., et al,, Meas. Sci. Technol, 14, (2003), pp.19631972.

(12) Ozaki, Y., et al., Exp. Thermal Fluid Sci., 26, (2004) pp.253-258.

(13) Sandrin, L., Manneville, S. and Fink, M., Appl. Phys. Lett., 78, (2001)pp.120-124.

(14) Ohbayashi, H., Takeda, Y. and Yamaguchi, K, Proc. 4th Int. Symp. Ultrasonic Doppler Method on Fluid Mech. and Fluid Eng., (2004) pp.125-128.

(15) Takeda, Y., invited paper to JSME Int. Journal, B38, (1995) pp.8-16.

(16) 日本機械学会編, 熱流体力学の新しい計測法, (1998) pp.148-163.

（17）菊地賢司他，特開 2002-148400,(2002).

（18）菊地賢司他，特願 2004-232028 号, (2004).

(19) Met-Flow SA, Lausanne, Switzerland, http:/www.metflow.ch/. 